\title{
The Myc-dependent angiogenic switch in tumors is mediated by interleukin $1 \beta$
}

\author{
Ksenya Shchors, ${ }^{1}$ Elena Shchors, ${ }^{2}$ Fanya Rostker, ${ }^{1}$ Elizabeth R. Lawlor, ${ }^{1,3}$ Lamorna Brown-Swigart, ${ }^{1}$ \\ and Gerard I. Evan ${ }^{1,4}$ \\ ${ }^{1}$ Cancer Research Institute and Department of Cellular and Molecular Pharmacology, University of California at San \\ Francisco Comprehensive Cancer Center, San Francisco, California 94143, USA; ${ }^{2}$ Biotraces, Inc., \\ Herndon, Virginia 20171, USA
}

\begin{abstract}
Although induction of blood vessel growth is acknowledged as a pivotal requirement for the evolution of macroscopic tumors, the events that trigger onset of tumor angiogenesis remain largely obscure. The pervasive Myc oncoprotein is itself a potent inducer of angiogenesis in a wide range of tissues. We have used a reversibly switchable mouse transgenic model of Myc-dependent $\beta$-cell carcinogenesis to delineate the kinetics and causal sequence of angiogenic processes following acute Myc activation. We show that onset of endothelial cell proliferation is induced shortly after Myc-induced cell cycle entry of $\boldsymbol{\beta}$ cells. Endothelial cell proliferation is not indirectly induced by local tissue hypoxia but instead via a diffusible angiogenic signal produced by Myc-expressing $\beta$ cells. This signal triggers the release of pre-existing, sequestered VEGF from the islet extracellular matrix, that then homes to the endothelial compartment where it induces endothelial cell proliferation. Myc activation in $\beta$ cells rapidly induces expression and release of the proinflammatory

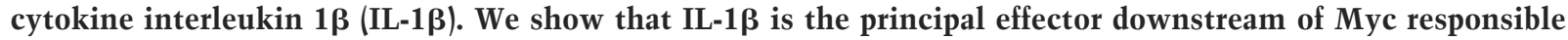
for triggering rapid onset of islet angiogenesis. Together, our data delineate a complete pathway in vivo by which the highly pleiotropic Myc oncoproteins elicits coexpansion of the vascular compartment during tumorigenic progression.
\end{abstract}

[Keywords: Myc; angiogenesis; interleukin $1 \beta$; tumor]

Supplemental material is available at http://www.genesdev.org.

Received June 6, 2006; revised version accepted July 26, 2006.

Induction of blood vessel growth is a pivotal requirement for the evolution of macroscopic tumors. However, the precise molecular mechanisms that trigger angiogenesis in tumors remains largely obscure. Some initial studies in experimental tumor models supported the notion that early tumors are innately incompetent for angiogenesis and, consequently, restricted in size by hypoxia and nutrient privation. The capacity for angiogenesis then arises sporadically during the course of tumor evolution, presumably through the aleatory acquisition of proangiogenic mutations. Recently, however, several studies have indicated that pervasive dominant oncogenes such as Myc and Ras can directly instruct angiogenesis in tissues in which they are activated (Watnick et al. 2003; Knies-Bamforth et al. 2004). Since oncogene activation is likely to be an early and obligate event in tumorigenesis, this intimates that angiogenesis can be an inherent attribute of many tumors from the outset.

${ }^{3}$ Present address: University of Southern California Keck School of Medicine, Children's Hospital Los Angeles, Division of Hematology-Oncology, 4650 Sunset Blvd., Los Angeles, CA 90027-6016, USA

${ }^{4}$ Corresponding author.

E-MAIL gevan@cc.ucsf.edu; FAX (415) 514-0878.

Article is online at http://www.genesdev.org/cgi/doi/10.1101/gad.1455706.
Deregulated expression of the basic helix-loop-helixleucine zipper (bHLH-LZ) transcription factor Myc is frequent in human cancers. Myc is a pivotal coordinator of a large number of diverse transcriptional programs that coordinate the cellular processes of growth, metabolism, proliferation, and intrinsic tumor suppression. In addition, Myc also regulates various processes by which proliferating cells communicate with, and instruct, appropriate changes in surrounding tissues and stroma, including angiogenesis, invasion, and tissue organization. In this way, Myc integrates intracellular processes required for cell expansion with requisite changes in the local somatic environment. The potent angiogenic action of Myc has been observed in experimental tumors of the skin (Pelengaris et al. 1999), pancreas (Pelengaris et al. 2002), in lymphoma (Brandvold et al. 2000), neuroblastoma (Fotsis et al. 1999), and transplanted Myc-expressing fibroblasts (Ngo et al. 2000). Such studies have variously implicated several, differing, angiogenic mechanisms, including direct down-regulation of the angiogenesis suppressor TSP1 (Watnick et al. 2003) and indirect promotion of local hypoxia and consequent activation of VEGF (Knies-Bamforth et al. 2004). However, such studies generally involve analysis of established tu- 
mors, making it difficult to identify the cause-and-effect sequence by which Myc triggers the angiogenic switch.

To explore how Myc drives tumor angiogenesis in vivo, we have used the pIns-MycER ${ }^{T A M} ; R I P 7-B c l-x_{L}$ mouse, a reversibly switchable orthotopic transgenic model of Myc oncogenesis in which the switchable form of the Myc oncoprotein, MycER ${ }^{\mathrm{TAM}}$, has been targeted to pancreatic $\beta$ cells via the proximal insulin promoter. Alone, acute activation of MycER ${ }^{\mathrm{TAM}}$ in $\beta$ cells triggers profound apoptosis. However, coexpression in $\beta$ cells of the anti-apoptotic protein Bcl- $\mathrm{x}_{\mathrm{L}}$ forestalls Myc-induced apoptosis, exposing the transcription factor's multifarious activities as an engine of cell growth, proliferation, dedifferentiation, invasion, and metastasis (Pelengaris et al. 2002; Lawlor et al. 2006). Sustained activation of Myc in $\beta$ cells of $p I n s-M y c E R^{T A M} ; R I P 7-B c 1-x_{L}$ mice triggers progressive expansion of $\beta$ cells synchronously in each of the several hundred pancreatic islets, an expansion accompanied lockstep by progressive dysplasia, anaplasia, angiogenesis, invasion, and metastasis. The rapidity and synchrony with which these multiple attributes of tumorigenesis arise indicates that they are instructed directly by Myc and not the consequence of sporadically acquired secondary mutations. It also permits direct examination of the kinetics, sequence, and mechanism by which Myc instructs the genesis of neoplasia in vivo. Here, we have used this type of kinetic analysis to delineate the pathway by which Myc triggers onset of angiogenesis in $\beta$-cell tumors.

\section{Results}

The onset of islet endothelial cell proliferation rapidly follows activation of Myc in $\beta$ cells

Previously, we showed that the sustained expansion of $\beta$ cells induced by persistent Myc activation in $p I n s-M y c-$ $E R^{T A M} ; R I P 7-B c l-X_{L}$ mice is accompanied by concurrent expansion and elaboration of islet vasculature (Pelengaris et al. 2002). To ascertain the kinetics of islet endothelial cell cycle entry following activation of Myc in $\beta$ cells, Myc was acutely activated in the $\beta$ cells of pIns$M y c E R^{T A M}{ }_{;} R P 7-B c l-x_{L}$ mice by systemic administration of 4-OHT and onset of $\beta$-cell $S$ phase monitored by staining pancreas sections from timed cohorts of mice for the proliferation marker Ki67. Following systemic (intraperitoneal) administration of 4-OHT, Myc is synchronously activated within $1-2 \mathrm{~h}$ in all $\beta$ cells, driving sequential activation of G1, then S, then G2-phase cyclins (Lawlor et al. 2006). This progression through the $\beta$-cell cycle is thenceforth maintained so long as Myc remains active (Fig. 1A; Pelengaris et al. 2002; Lawlor et al. 2006). Interestingly, analysis of all cells within islets revealed that the cellular proliferation induced by Myc is not limited to the $\beta$-cell compartment. Using Meca-32 expression as a marker of endothelial cells, we could identify proliferating Ki-67-positive endothelial cells as early as $48 \mathrm{~h}$ after 4-OHT administration (Fig. 1B), even though such cells express no endogenous MycER ${ }^{\mathrm{TAM}}$.
Subsequent deactivation of Myc led to rapid withdrawal of both $\beta$ and endothelial islet cells from cycle (Supplementary Fig. 1), consistent with our previous observations (Pelengaris et al. 2002) that Myc is required to maintain islet expansion and angiogenesis. Control animals treated with oil carrier instead of 4-OHT exhibited no measurable proliferation in either $\beta$-cell or endothelial cell compartments (Supplementary Fig. 1). Control RIP7-Bcl- $x_{L}$ mice treated for $7 \mathrm{~d}$ with 4-OHT exhibited no evidence of proliferation in either $\beta$-cell or islet endothelial compartments (Supplementary Fig. 1).

Mitogenesis of endothelial cells in pIns-MycER ${ }^{\text {TAM}}$; RIP7-Bcl- $\mathrm{x}_{\mathrm{L}}$ islets occurs without tissue hypoxia

Since MycER ${ }^{\text {TAM }}$ is not expressed within the vascular compartment, the rapid onset of endothelial cell proliferation we observe in 4-OHT-treated pIns-MycER ${ }^{T A M}$; $R I P 7-B c 1-X_{L}$ mice must be due to some mitogenic influence arising from the adjacent Myc-expressing $\beta$-cell compartment. One potent inducer of endothelial cell proliferation and angiogenesis is hypoxia. Below a $\mathrm{pO}_{2}$ of $\sim 40$ torr $(\sim 7 \%)$, the HIF1 $\alpha$ component of the HIF-1 transcription factor is stabilized (Semenza 2001), whereupon activated HIF-1 orchestrates a pleiotropic downstream response that regulates direct and adaptive responses to depleted oxygen (Harris 2002), including induction of angiogenic factors such as VEGF. To ascertain whether hypoxia might be the trigger for endothelial cell proliferation following Myc activation, pimonidazole hydrochloride was systemically administered to $\mathrm{PInS}-M y c E R^{T A M}$; RIP7-Bcl- $X_{L}$ mice following 4-OHT treatment. Pimonidazole hydrochloride forms immunohistochemically detectable protein adducts when reductively activated and so serves as an effective marker of tissue hypoxia in vivo. As positive controls we used mice harboring extremely large islet tumors arising from sustained Myc activation in pIns-MycER ${ }^{T A M} ; R I P 7-B c l-x_{L} ; A R F^{-/}$mice (Finch et al., 2006) and the proximal tubes in kidney from 6-d postpartum wild-type mice, which are known to exhibit significant tissue hypoxia (Freeburg and Abrahamson 2004). Although pimonidazole adducts were clearly visible in the large, established pIns-MycER ${ }^{T A M} ; R I P 7-B c l-x_{L} ; A R F$ $K O$ islet tumors and in kidney proximal tubules (Supplementary Fig. 2), no staining indicative of hypoxia was detectable in $p I n s-M y c E R^{T A M}{ }_{;} R I P 7-B c l-x_{L}$ islet tissue at $72 \mathrm{~h}$ following Myc activation in $\beta$ cells (Fig. 2), which is the time window during which proliferation in endothelial cell compartment is induced (Fig. 1B).

In the absence of tissue hypoxia, the most likely cause of endothelial proliferation in Myc-active $p I n s-M y c E R^{T A M}$; $R I P 7-B c l-X_{L}$ islets is a direct mitogenic signal generated by Myc-expressing $\beta$ cells. To assess whether such a trans-active signal exists, islets were isolated from pancreata of $p I n s-M y c E R^{T A M} ; R I P 7-B c l-x_{L}$, explanted into culture, and MycER ${ }^{\mathrm{TAM}}$ protein was activated for $3 \mathrm{~d}$ by the addition of $100 \mathrm{nM} 4-\mathrm{OHT}$ to the culture medium. The culture medium was then removed and assayed for its ability to promote proliferation and induce tubulogen- 

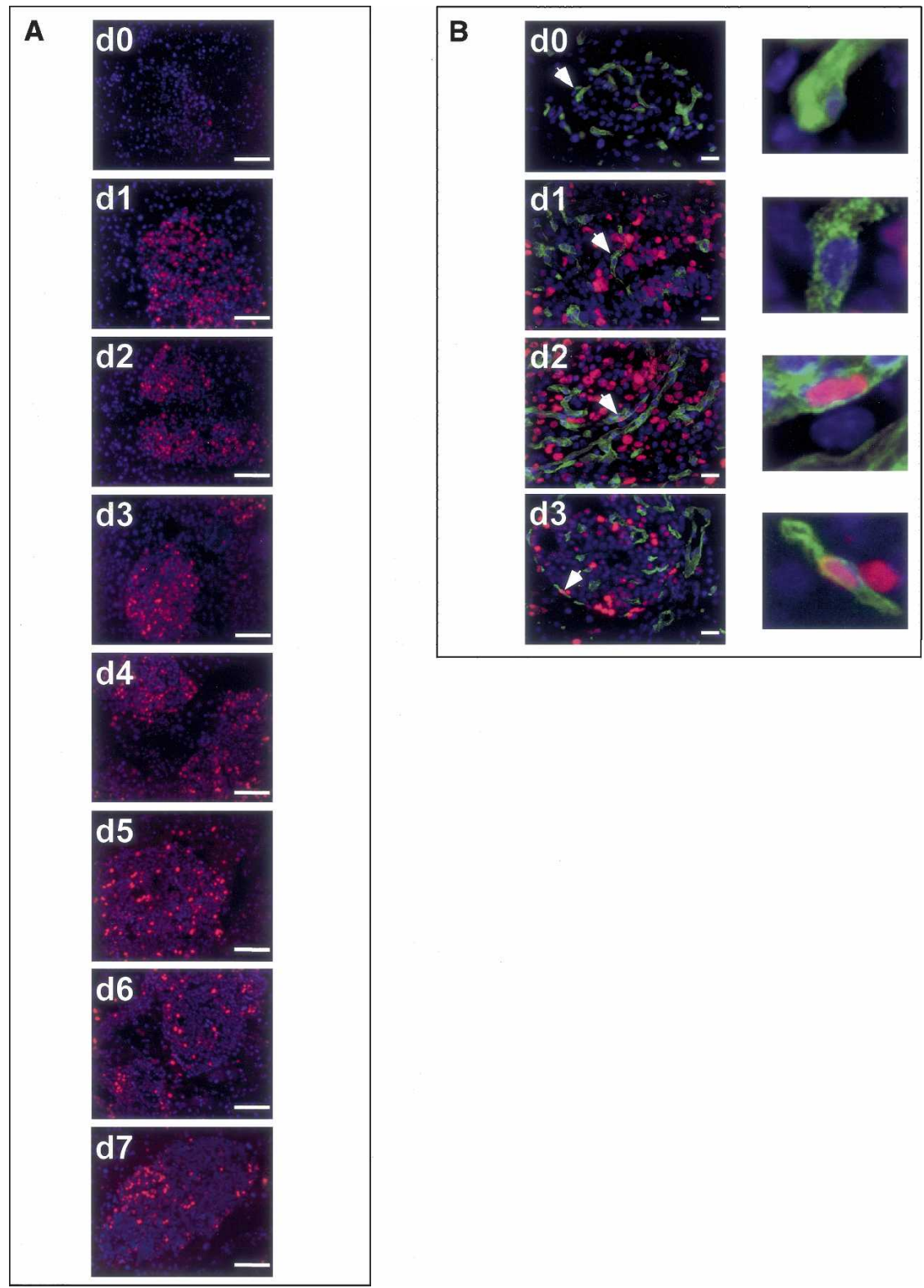

esis in subconfluent primary human umbilical vein endothelial cells (HUVEC). Addition of 4-OHT to pIns$M y c E R^{T A M} ; R I P 7-B c l-x_{L}$ islets in vitro had no discernible effect on islet morphology and survival over $72 \mathrm{~h}$ (data not shown). Media derived from such cultures promoted marked HUVEC streaming and assembly into extended, tubular structures, indicative of the de novo presence of angiogenic factors (Fig. 3A). Quantitative analysis of HUVEC cells showed that nearly $80 \%$ of HUVEC cells cultured in conditioned media derived from 4-OHT-treated (Myc ON) islets were incorporated into tubelike structures, compared with $40 \%$ of HUVEC cells cultured in control media from islets treated with ethanol vehicle control (Myc OFF) (Fig. 3B). Addition of 4-OHT itself had no effect on HUVEC survival or disposition (data not shown). Thus, activation of Myc in $\beta$
Figure 1. Activation of Myc in $\beta$ cells of pancreatic islets induces rapid, Myc-dependent onset of $\beta$-cell and islet endothelial cell proliferation. Cohorts of pIns-c$M y c E R^{T A M} ; R I P 7-B c l-x_{L}$ double-transgenic mice were treated with 4-OHT daily for 7 $\mathrm{d}(\mathrm{d} 0-\mathrm{d} 7)$ and pancreata were isolated and analyzed by IHC. (A) Total cell proliferation in islets was assessed by Ki67 staining (red). Cells were counterstained with Hoechst (blue). $\beta$ Cells within panreatic islets initiate S-phase entry within $24 \mathrm{~h}$ of Myc activation. Bars, $100 \mu \mathrm{m}$. (B) Proliferating endothelial cells were identified by colabeling with the endothelial marker Meca-32 (green), Ki67 (red), and Hoechst (blue). Initiation of proliferation in the Meca-32-positive endothelial cells of islets was evident as early as $48 \mathrm{~h}$ after Myc activation and persisted as long as Myc was activated. Bars, $20 \mu \mathrm{m}$. cells induces production and release of a diffusible proangiogenic factor from islets.

\section{Myc regulates VEGF A accessibility} in pIns-c-MycER ${ }^{\mathrm{TAM}}{ }_{\text {; RIP7-Bcl- }}$ islets

Myc-induced islet angiogenesis exhibits classical hallmarks of tumor vasculature, including tortuous and immature vessel branching and leakiness (Fig. 4; Pelengaris et al. 2002). These attributes are typically elicited by the vascular remodeling factor VEGF A, which promotes both vascular elaboration and vessel permeability (Dvorak 2002). To test whether VEGF A is responsible for the Myc-induced endothelial proliferation and angiogenesis we observe, media derived from $p I n s-M y c E R^{T A M}$; RIP7-Bcl- $X_{L}$ islets were collected 24,48 , and $72 \mathrm{~h}$ fol- 

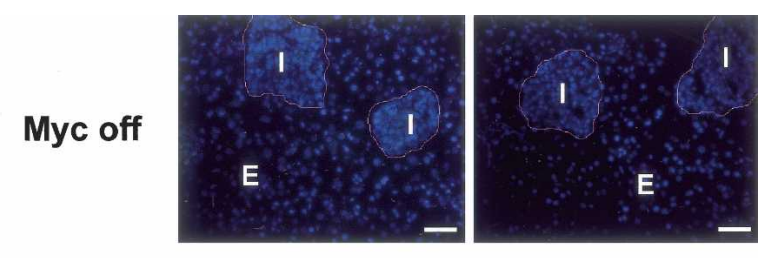

\section{Myc on}
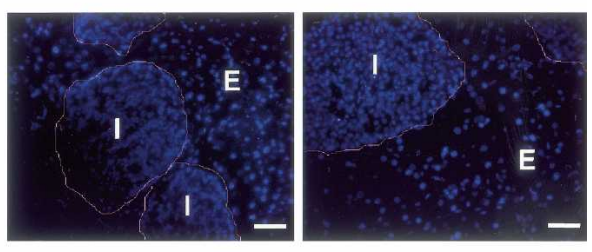

\section{Advanced $\beta$ cell tumor}

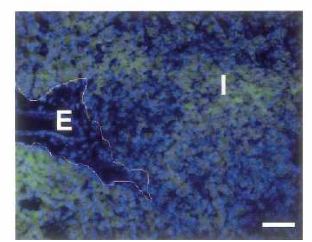

Figure 2. Myc-induced islet endothelial proliferation occurs in the absence of tissue hypoxia. pIns-c-MycER ${ }^{T A M} ; R I P 7-B c l-x_{L}$ mice were treated daily with 4-OHT for $3 \mathrm{~d}$ to activate Myc (Myc ON) or with oil carrier for $24 \mathrm{~h}$ (Myc OFF). Hypoxyprobe was then administered as described in Materials and Methods and sections from pancreatic tissue analyzed for the presence of hypoxia by staining with Anti-Hypoxyprobe. Islet/ $\beta$-cell (I) and exocrine (E) pancreatic tissue are indicated. The figure shows two independent and representative studies. As a positive control for tissue hypoxia, pIns-c-MycER ${ }^{T A M} ; R I P 7-B c l-x_{L} ; A R F^{-/-}$ mice, which rapidly develop very large, invasive, and aggressive tumors ("advanced $\beta$-cell tumor") upon sustained Myc activation, were treated with 4-OHT daily for $21 \mathrm{~d}$. These animals were then injected with Hypoxyprobe prior to sacrifice, and areas of pancreatic tissue/tumor hypoxia were identified as above. Bars, $50 \mu \mathrm{m}$.

lowing MycER ${ }^{\mathrm{TAM}}$ activation in vitro and VEGF A content then assayed by ELISA. Stimulation of pIns$M y c E R^{T A M}{ }_{;} R I P 7-B c l-x_{L}$ islets with 4-OHT induced marked VEGF A accumulation in culture supernatants at $48 \mathrm{~h}$ (2.5-fold) and $72 \mathrm{~h}$ (fourfold) when compared with ethanol-treated controls (Fig. 4A). No 4-OHT-dependent induction of VEGF A was evident in culture supernatants derived from islets purified from MycER ${ }^{\mathrm{TAM}}$-negative RIP7-Bcl- $x_{L}$ mice (Fig. 4A). Thus, Myc activation in $\beta$ cells induces production of VEGF A.

MycER ${ }^{\text {TAM }}$ is activated very rapidly following 4-OHT addition to cultured cells or after systemic administration of 4-OHT to animals (Pelengaris et al. 2002), leading to modulation of Myc target genes within 60-120 min (Lawlor et al. 2006). However, no measurable accumulation of VEGF A mRNA could be detected at 4, 8, or $24 \mathrm{~h}$ after MycER ${ }^{\text {TAM }}$ activation (Fig. 4B; Lawlor et al. 2006). Similarly, quantitative real-time PCR analysis of isolated islets in vitro showed no induction of VEGF $A$ expression following MycER ${ }^{\mathrm{TAM}}$ activation (data not shown). Affymetrix analysis indicated that expression of other prominent candidates for Myc-dependent angiogenesis, including VEGF $B, T N F-\alpha, F G F A, P D G F A$, and
TSP-1 was also unaffected (up or down) by Myc activation over the initial 24-h period (Lawlor et al. 2006; data not shown). Thus, Myc appears not to directly modulate expression of any obvious angiogenic signaling molecules.

Although Myc activation in $\beta$ cells induces no measurable change in VEGF $A$ expression in islets, as reported previously (Bergers et al. 2000) islets already express significant levels of VEGF A mRNA constitutively (Fig. 4B). In the main, this constitutive VEGF A appears to be sequestered in an inactive state by the islet extracellular matrix (ECM), and induction of tumor angiogenesis in the well-characterized RIP-Tag islet tumor model coincides with release of this sequestered VEGF through the action of extracellular proteases (Bergers et al. 2000). Knowing this, we examined immunohistochemically the tissue distribution and disposition of VEGF before and after acute Myc activation in islets derived from pIns-MycER ${ }^{T A M} ; R I P 7-B c l-X_{L}$ mice. As predicted by VEGF A mRNA analysis, the total level of VEGF A in islets was broadly unaffected by Myc status. However, Myc activation induced a dramatic redistribution of islet

A
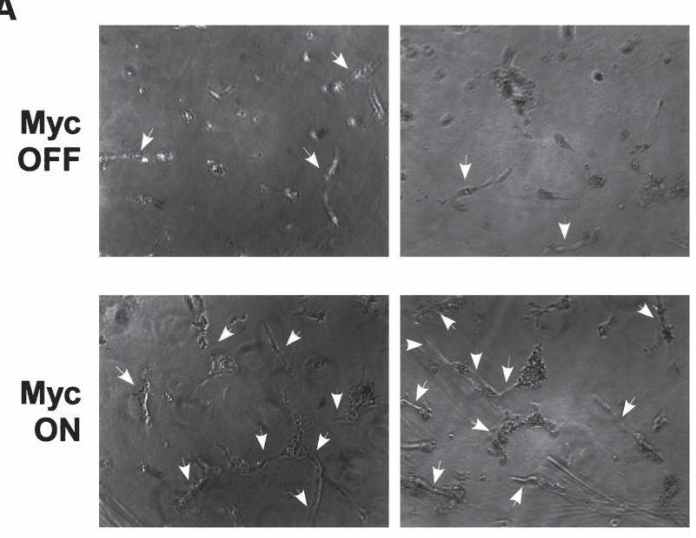

B

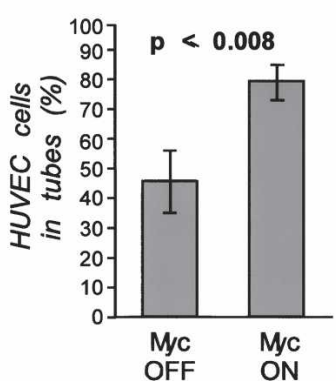

Figure 3. Myc activation in $\beta$ cells in islets induces production of diffusible angiogenic factors in vitro. Islets were isolated from pIns-MycER ${ }^{T A M} ;$ RIP7-Bcl- $x_{L}$ mice and incubated in media containing either 4-OHT (Myc ON) or EtOH carrier (Myc OFF). Medium from these cultures was then used to treat HUVEC seeded in a fibrinogen sandwich for $72 \mathrm{~h}$. (A) HUVEC tubule formation was assayed microscopically. Tubelike structures are indicated by arrows. Two independent and representative studies are shown. $(B)$ The proportion of HUVEC cells incorporated into tubelike structures was determined after application of media conditioned by Myc ON or Myc OFF islets, as described in Materials and Methods. 

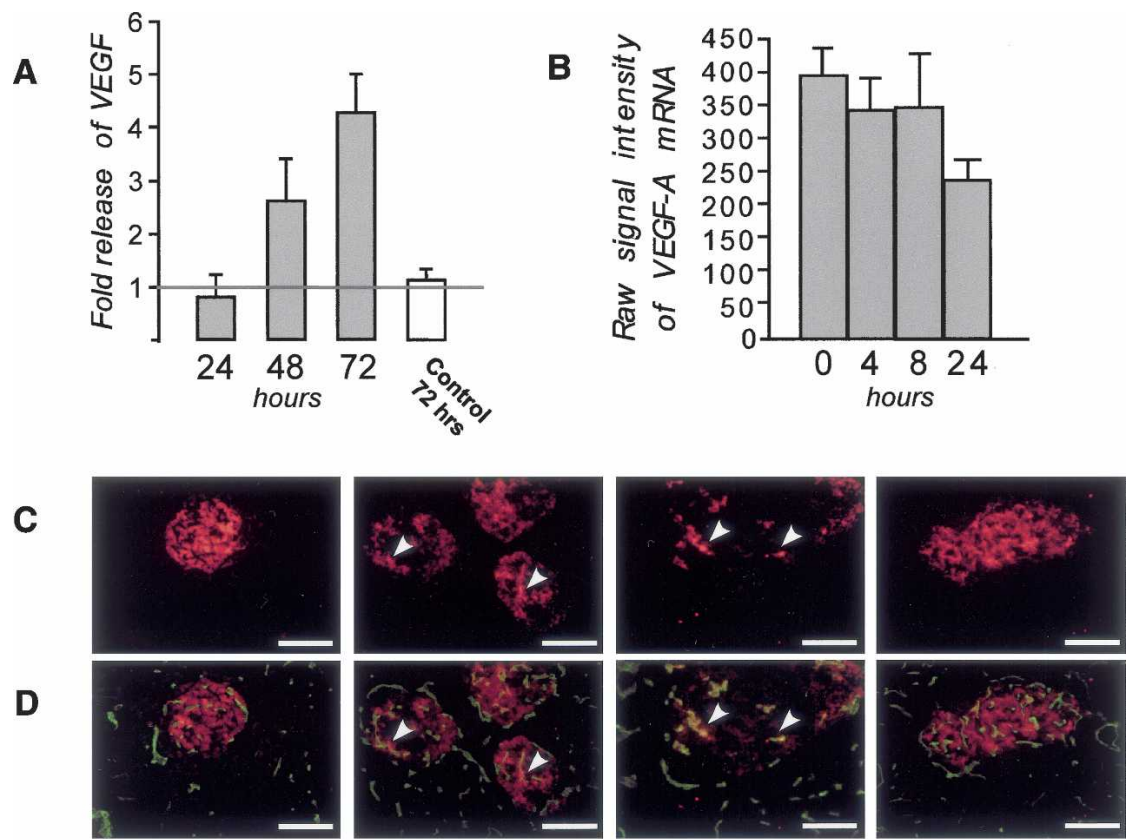

E
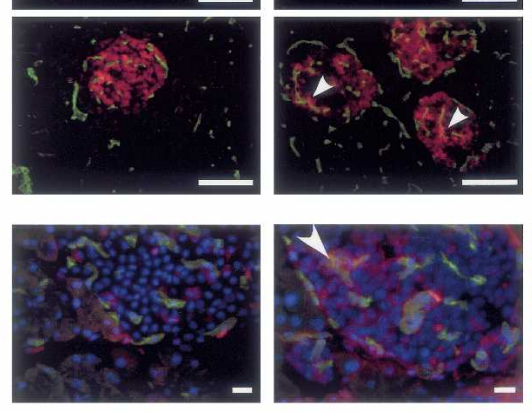

F

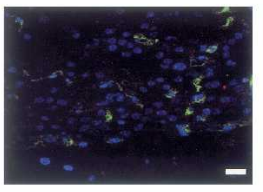

Myc OFF

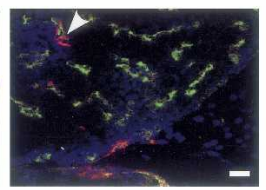

d3
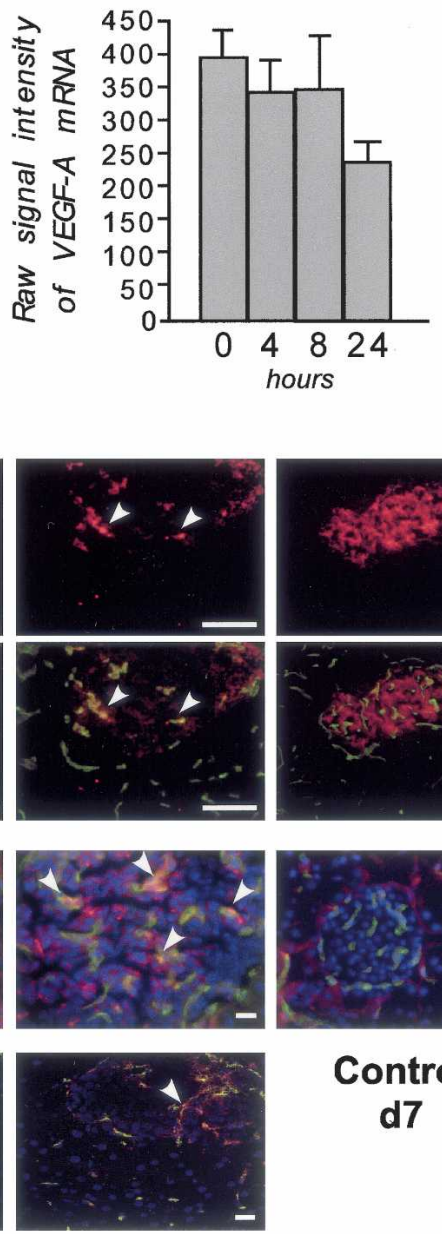

d7

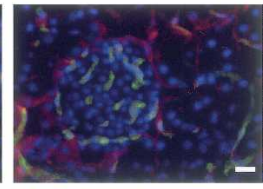

Control d7

Figure 4. Myc drives release and relocalization of VEGF in vitro and in vivo. (A) Islets isolated from pIns-c$M y c E R^{T A M} ; R I P 7-B c l-x_{L}$ were cultured in vitro in the presence of either 4-OHT or vehicle control (EtOH), culture media were harvested at the time points indicated, and VEGF A was assayed by ELISA. The graph represents VEGF A induction by Myc relative to that in EtOHtreated samples at the time points indicated. As a control, media were isolated from Myc-negative RIP7-Bcl- $x_{L}$ islets treated in vitro for $72 \mathrm{~h}$ with 4-OHT or control vehicle, and VEGF A production was determined as described above. $(B)$ Quantitative analysis of Myc activation on VEGF A mRNA expression islets in vivo by Affymetrix GeneChip Array. 4-OHT was systemically administered to $p I n s-M y c E R^{T A M} ; R I P 7-B c l-x_{L}$ mice for $0,4,8$, or $24 \mathrm{~h}$. Islet tissue derived from pancreas sections was then laser captured, RNA was extracted, and VEGF A was expression quantitated. $(C)$ Rapid redistribution of VEGF A in islets by $72 \mathrm{~h}$ after Myc activation in $\beta$ cells. pIns$M y c E R^{T A M} ; R I P 7-B c l-x_{L}$ mice were treated with 4-OHT daily as in Figure 1. At the times indicated, animals were sacrificed and the pancreata was isolated, sectioned, and stained with antiVEGF A antibody (red). Areas of focal VEGF A accumulation are indicated with arrows. Bars, $100 \mu \mathrm{m}$. (D) Redistributed VEGF localizes to endothelial cells. The same sections as in $C$ were incubated with antibody specific to the endothelial cell marker Meca-32 (green), showing significant overlap between VEGF foci and endothelial cells. Bars, $100 \mu \mathrm{m} .(E)$ Redistributed VEGF is engaged with its cognate Flk-1 receptor. Pancreata sections were incubated with both the VEGF:Flk-1 complexspecific antibody GVM39 (red) and anti-Meca-32 (green). Hoechst (blue) was used as counterstain. Instances of colocalization of VEGF:VEGFR complex with Meca-32-positive cells are shown by the arrows. Bars, $20 \mu \mathrm{m}$. (F) Myc-induced mobilization of VEGF induces leakiness of islet vasculature. pIns-c-MycER ${ }^{T A M} ; R I P 7-B c l-x_{L}$ animals treated with 4-OHT for the times indicated were perfused with FITC-Lycopersicon esculentum lectin, which binds to the luminal surface of blood vessels, and Rhodamine-Ricinus communis agglutinin, which binds the endothelial basement membrane. Regions of vasculature leakage are indicated by arrows. Bars, $20 \mu \mathrm{m}$.

VEGF A from a diffuse disposition throughout the islet to discrete foci within the islet mass (indicated by arrows in Fig. 4C). This redistribution is highly reminiscent of that observed during the sporadic angiogenic switch in RIP-Tag $\beta$-cell tumors. Furthermore, we could identify the discrete VEGF foci induced by Myc activation in islet sections as sites of endothelial cells by costaining with antibodies specific for VEGF A and the endothelial cell marker Meca-32 (Fig. 4D). Staining with the GVM39 antibody that specifically recognizes VEGF:VEGFR2 (Flk1)ligated conjugates indicated that VEGF A within these foci is associated with its cognate receptor (Fig. 4E). The onset of this VEGF redistribution ( $72 \mathrm{~h}$ ) correlated with onset of endothelial cell mitogenesis, and the redistribution was maintained so long as Myc function was sustained. Subsequent deactivation of Myc induced rapid reversal of VEGF A relocalization, back to a diffuse dis- tribution (Supplementary Fig. 3). Thus, Myc activity is required not only to induce, but also to maintain, VEGF A redistribution. No analogous changes in VEGF A distribution were observed in $M y c E R^{T A M}$-negative control mice following 4-OHT treatment, indicating that the effect is specific to Myc (Fig. 4C-E). Since VEGF A is not just a mitogen but also a potent vascular permeability factor (Abraham et al. 2002), we also assessed the leakiness of Myc-induced islet vasculature by systemic perfusion of mice with Ricinus communis agglutinin I (RCA-I), which binds subendothelial basement membrane only when extravasated. Substantial vascular leakiness became evident by 72-96 h after Myc activation in $\beta$ cells (Fig. 4F). This onset of vessel leakiness is consistent with both the known properties of VEGF A and with the kinetics of VEGF redistribution and ligation to receptors on islet endothelial cells. 
Interleukin $1 \beta$ (IL-1 $\beta)$ mediates Myc-induced release and activation of VEGF $A$ and onset

of tumor angiogenesis

Matrix metalloproteinases have previously been implicated in triggering the release of ECM-sequestered VEGF during the angiogenic switch of islet tumors in the RIPTag model (Bergers et al. 2000). Indeed, de novo MMP activity was detectable in isolated islets at the time of VEGF redistribution, suggesting a similar role for MMPs in Myc-induced angiogenesis. However, none of the genes encoding the likely candidate metalloproteinases (MMP2, MMP3, and MMP9) was induced following Myc activation (Lawlor et al. 2006; data not shown), indicating that onset of MMP activity is an indirect consequence of Myc activation. In addition to gene expression, MMP activity is regulated at multiple levels, including proteolytic activation of the inactive MMP precursor zymogen, interaction with endogenous inhibitors such as TIMPs, sequestration by ECM and adhesion molecules, and proteolytic inactivation (Osenkowski et al. 2004). To search for any of the diverse candidate intermediaries responsible for Myc-dependent MMP activation, we examined our $\beta$-cell Myc target gene database and identified the gene encoding IL-1 $\beta$, a cytokine implicated in acute and chronic inflammation and a potent activator of metalloproteinase activity. By comparison, expression of TGF- $\beta$ and TNF- $\alpha$, other well-described promoters of MMP activity, was unaffected by Myc activation. Induction of $I L-1 \beta$ transcription in islets was evident as early as $2 \mathrm{~h}$ after MycER ${ }^{\mathrm{TAM}}$ activation in $\mathrm{pIns}-M y c E R^{\text {TAM}}$; $R I P 7-B c l-X_{L} \beta$ cells in vivo. No $I L-1 \beta$ was induced by 4-OHT treatment of $M y c E R^{T A M}$-negative animals (Fig. $5 \mathrm{~A})$.

The rapid induction of $I L-1 \beta$ mRNA expression by Myc in islets was confirmed in vitro by quantitative realtime PCR analysis of mRNA isolated from cultured islets (Fig. 5B). Such induction of $I L-1 \beta$ mRNA was accompanied by substantial (12-fold) increase in IL-1 $\beta$ protein $24 \mathrm{~h}$ after Myc activation in pIns-MycER ${ }^{T A M} ;$ RIP7-Bcl$X_{L}$ islets in vitro (Fig. $5 \mathrm{C}$ ). In contrast, culture supernatants from $R I P 7-B c l-x_{L}$ islets lacking the $M y c E R^{T A M}$ transgene produced no measurable IL-1 $\beta$ following the exposure to 4-OHT. Thus, $I L-1 \beta$ mRNA and protein expression are rapidly induced following Myc activation in $\beta$ cells, and this induction precedes release of VEGF A from the islet ECM.

To test directly whether IL- $1 \beta$ has a causal role in mediating Myc-induced angiogenesis, we used IL-1 $\beta$-neutralizing antibodies to interfere with IL-1 $\beta$ activity in vitro and in vivo. First, islets derived from pIns$M y c E R^{T A M} ; R I P 7-B c l-x_{L}$ mice were explanted into culture and Myc activated by addition of $100 \mathrm{nM} 4-\mathrm{OHT}$ to the culture medium for $3 \mathrm{~d}$, either alone or in the presence of control or IL-1 $\beta$-neutralizing antibody. VEGF levels were then assayed in culture supernatants by ELISA. Blocking anti-IL-1 $\beta$ antibodies significantly reduced the production of VEGF by these explanted islets following Myc activation, compared with islets incubated in the absence of antibodies or with control IgG (Fig. 6A). Fur-
A

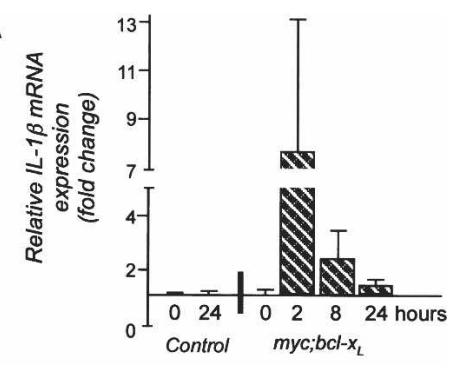

B



C

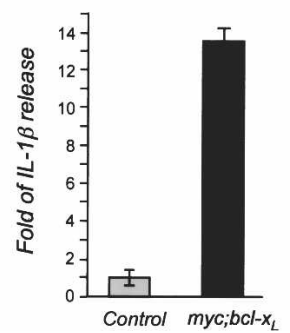

Figure 5. Myc induces IL-1 $\beta$ expression in vivo and in vitro. $(A)$ Myc activation in $\beta$ cells rapidly induces $I L-1 \beta$ mRNA expression in vivo. 4-OHT was systemically administered to either pIns-MycER ${ }^{\text {TAM }}$;RIP7-Bcl- $x_{L}(0,2,8,24 \mathrm{~h})$ or to Myc-negative $R I P 7-B C l-x_{L}(0$ and $24 \mathrm{~h}$ ) control mice. Pancreata were then harvested, frozen, and sectioned, and islet tissue was isolated by laser capture microdissection. $I L-1 \beta$ mRNA expression was analyzed by Affymetrix GeneChip Arrays and is presented as fold of induction relative to untreated samples. (B) Myc activation in $\beta$ cells rapidly induces expression of $I L-1 \beta$ mRNA in isolated islets in vitro. Islets isolated from $p I n s-M y c E R^{T A M} ; R I P 7-B c l-x_{L}$ mice were cultured in vitro for $4 \mathrm{~h}$ in the presence of either 4-OHT (Myc ON) or control ethanol vehicle (Myc OFF). IL-1 $\beta$ mRNA expression was assayed by quantitative real-time PCR. (C) Myc activation in $\beta$ cells induces release of IL-1 $\beta$. Islets isolated from $p I n s-M y c E R^{T A M}{ }_{;} R I P 7-B c l-x_{L}$ or control Myc-negative $R I P 7-B c l-x_{L}$ mice were cultured for $24 \mathrm{~h}$ in either $100 \mathrm{nM}$ 4-OHT or an equivalent concentration of ethanol vehicle control. IL- $1 \beta$ accumulation in culture supernatants was then assayed by ELISA. The graph represents IL- $1 \beta$ induction in 4-OHT-treated samples relative to samples treated with ethanol.

thermore, addition of recombinant IL-1 $\beta$ for $3 \mathrm{~d}$ to isolated pIns-MycER ${ }^{T A M} ; R I P 7-B c l-x_{L}$ islets triggered significant release of VEGF A compared with controls (Fig. $6 \mathrm{~A})$, indicating that VEGF A release is downstream of IL- $1 \beta$ activity in vitro. To validate the angiogenic role of IL- $1 \beta$ in vivo, IL- $1 \beta$ was blocked in $p I n s-M y c E R^{T A M}{ }_{;}$RIP$B c l-X_{L}$ mice in vivo by daily systemic administration of IL-1 $\beta$-neutralizing antibodies (Hwang et al. 2001). Serum ELISA analysis of IL- $1 \beta$ indicated essentially complete absence of immunologically detectable IL-1 $\beta$ in animals 
A

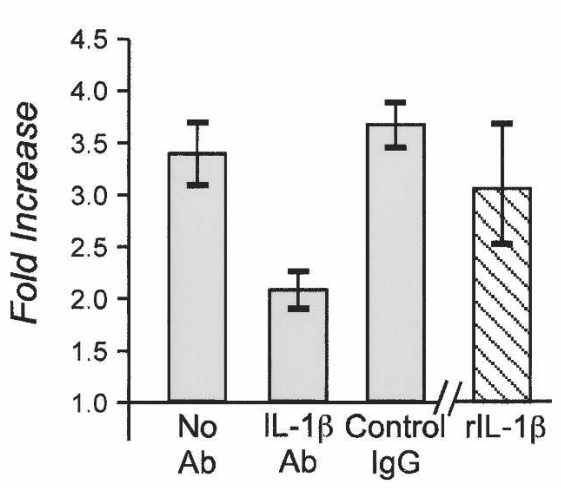

B

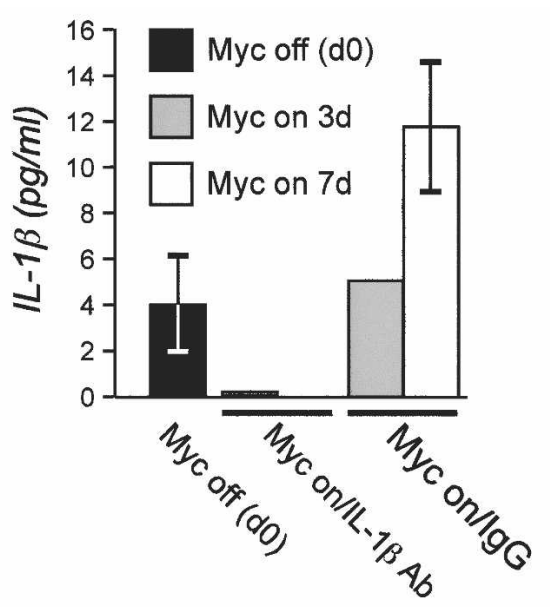

C

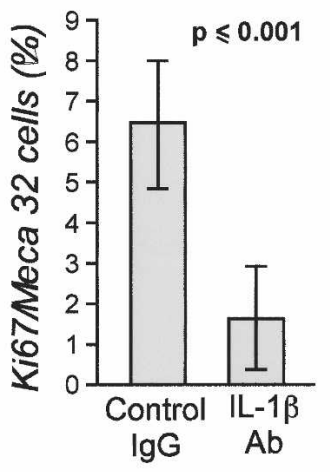

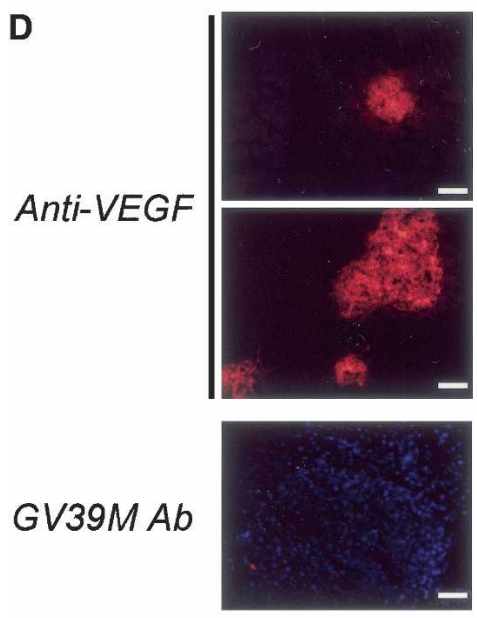

Myc OFF
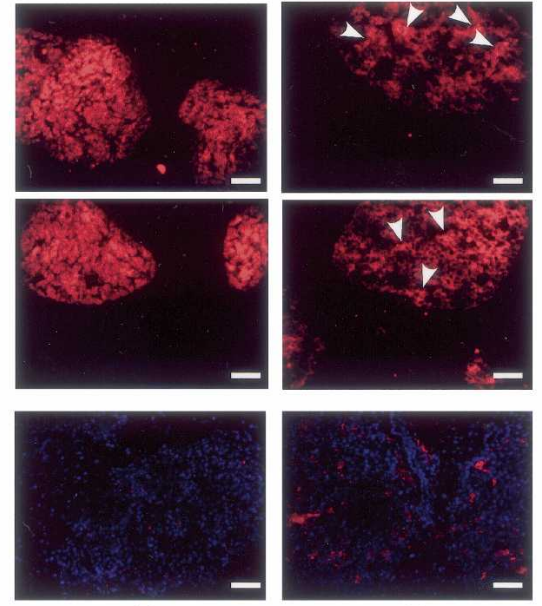

d3 anti-IL-1 $\beta A b$

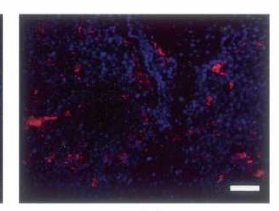

d3
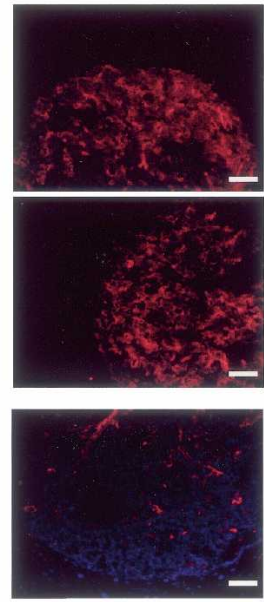

$d 7$

anti-IL-1 $\beta A b$
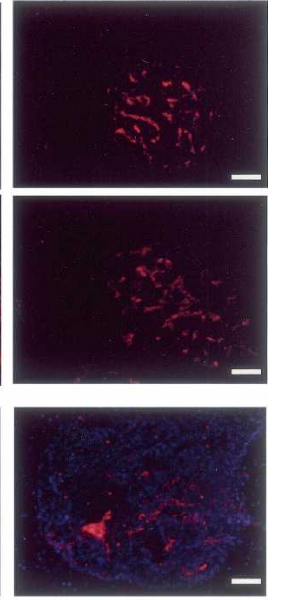

$d 7$

Control lgG

Figure 6. IL-1 $\beta$ is both necessary and sufficient to mediate Myc-induced release of VEGF and onset of islet neo-angiogenesis. $(A)$ IL-1 $\beta$-neutralizing antibodies block Myc-induced release of VEGF from islets in vitro while recombinant IL-1 $\beta$ triggers VEGF release. Islets isolated from $p I n s-M y c E R^{T A M} ; R I P 7-B c l-x_{L}$ mice were treated in vitro for $72 \mathrm{~h}$ with $100 \mathrm{nM} 4-\mathrm{OHT}$ alone (No Ab), or in the presence of $0.1 \mu \mathrm{g} / \mathrm{mL}$ IL-1 $\beta$-neutralizing antibodies (IL-1 $\beta \mathrm{Ab}$ ) or control goat IgG. Culture media were then collected and VEGF A levels were assayed by ELISA. The solid bars show VEGF A induction by 4-OHT relative to samples treated with ethanol for $72 \mathrm{~h}$. To ascertain the direct effect of IL- $1 \beta$ on isolated islets, recombinant IL- $1 \beta$ (rIL-1 $\beta$ ) was added to isolated $p I n s-M y c E R^{T A M} ; R I P 7-B c l-x_{L}$ islets to a final concentration of $10 \mathrm{ng} / \mathrm{mL}$, and culture medium was assayed for released VEGF $72 \mathrm{~h}$ later. The shaded bar indicates fold VEGF release over that in medium isolated from control islets treated with ethanol carrier. $(B)$ Systemic administration of AB-401-NA anti-IL-1 $\beta$ antibody neutralizes circulating IL-1 $\beta$. Sera were collected from control (untreated, Myc OFF) $p I n s-M y c E R^{T A M}$; RIP7-Bcl- $x_{L}$ mice, $p I n s-M y c E R^{T A M} ; R I P 7-B c l-x_{L}$ mice systemically treated with AB-401-NA antibody (Myc ON/IL-1 $\beta$ Ab), and $p I n s-$ MycER ${ }^{T A M}$; RIP7-Bcl- $x_{L}$ mice systemically treated with control goat IgG (Myc ON/IgG) for 3 or 7 d. Sera were then assayed for immunologically detectable IL-1 $\beta$ by ELISA. (C) Systemic neutralization of IL-1 $\beta$ significantly inhibits Myc-induced islet endothelial cell proliferation. Pancreata were harvested from $p I n s-M y c E R^{T A M} ; R I P 7-B c l-x_{L}$ mice treated daily for $3 \mathrm{~d}$ with $4-\mathrm{OHT}$ together with either goat IgG (Control IgG) or AB-401-NA anti-IL-1 $\beta$ antibody. The percentage of Meca-32-positive cells that also stained positive for the proliferation marker Ki67 was then determined. The combined results from three independent experiments are presented. In each experiment, differing tissue samples from each animal were analyzed twice and the proportions of Ki67-positive endothelial cells were assessed in at least 10 independent islets. $(D)$ Systemic neutralization of IL-1 $\beta$ significantly inhibits Myc-induced islet angiogenesis. Pancreata were harvested from $p I n s-M y c E R^{T A M} ; R I P 7-B c l-x_{L}$ mice treated daily for either 3 or $7 \mathrm{~d}$ with 4 -OHT plus either AB-401-NA antibody (anti-IL-1 $\beta \mathrm{Ab}$ ) or control goat IgG. As Myc-negative controls, $p I n s-M y c E R^{T A M}{ }_{;} R I P 7-B c l-X_{L}$ mice were treated with control vehicle in place of 4-OHT. Pancreas sections were stained with antibody to VEGF A (red). The top two rows show two representative examples for each experimental cohort. VEGF A foci are indicated by arrows. The bottom row shows VEGF:Flk-1 ligated complexes in islets, identified by staining sections with GVM39 antibody (red) and counterstaining tissue with Hoechst (blue). Bars, $50 \mu \mathrm{m}$.

treated with blocking antibody (Fig. 6B). Systemic inhibition of IL-1 $\beta$ in vivo significantly reduced the efficiency with which activation of Myc in the $\beta$-cell com- partment induces endothelial cells proliferation in islets, but without any measurable inhibition of $\beta$-cell proliferation, at least over the 7-d time course of our study 
(Fig. 6C). Furthermore, systemic IL-1 $\beta$ inhibition suppresses and delays the redistribution of VEGF to islet endothelial cells in vivo that Myc induces. After $3 \mathrm{~d}$ sustained Myc activation in control IgG-treated mice, significant islet VEGF has visibly relocated to endothelial foci. Staining with the GVM39 antibody indicates that this relocalization coincides with VEGF binding to its cognate Flk-1 receptor. After $7 \mathrm{~d}$ Myc activity, relocalization of VEGF to the expanding islet vasculature is essentially complete. In contrast, islets from mice treated with IL-1 $\beta$ blocking antibody retain diffuse VEGF staining after $3 \mathrm{~d}$ Myc activity, with no detectable VEGF receptor ligation (Fig. 6D). Although VEGF-Flk-1 conjugates are detectable in IL-1 $\beta$-blocked islets by day 7 , the extent of VEGF redistribution is still significantly reduced relative to controls, indicating the key role played by $\mathrm{IL}-1 \beta$ in the onset of Myc-induced tumor angiogenesis.

\section{Discussion}

Our previous studies showed that acute activation in vivo of the switchable form of Myc, MycER ${ }^{\mathrm{TAM}}$, in pancreatic $\beta$ cells in which Myc-induced apoptosis is blocked by coexpression of $\mathrm{Bcl}-\mathrm{x}_{\mathrm{L}}$ induces rapid, uniform, and progressive $\beta$-cell expansion in each of the several hundred islets within the pancreas. As each $\beta$-cell population expands, so it spontaneously acquires many of the characteristics of more advanced tumors, including angiogenesis, dedifferentiation, anaplasia, and local and distal invasion. The rapidity and synchrony within each $\beta$-cell mass indicates that they are not the consequence of sporadic secondary mutations but, instead, are instructed directly by Myc. This notion is consistent with the emerging role of Myc as a highly pleiotropic transcriptional coordinator of cell expansion, linking intracellular programs for cell growth, proliferation, and checkpoint management to extracellular programs that coordinate such proliferation with neighboring cells and stroma.

Angiogenesis requires the extensive proliferation and remodeling of endothelial cells. The rapid onset of islet angiogenesis induced by Myc in $\beta$ cells indicates that Myc must equip $\beta$ cells with the capacity to instruct necessary mitogenic and organizational changes in the accompanying islet endothelial compartment. Using the rapid, reproducible, and reversible kinetics of the MycER ${ }^{\mathrm{TAM}}$ system, we have explored both the kinetics and mechanism of this Myc-mediated angiogenic switch. We show that islet endothelial cells enter the cell cycle rapidly following Myc activation in $\beta$ cells. Indeed, a delay of only $24-48 \mathrm{~h}$ separates cell cycle entry of $\beta$ cells and neighboring endothelial cells, even though the former is directly instructed by Myc and the latter only indirectly. Moreover, the onset of angiogenesis temporally coincides with release of sequestered VEGF A within each islet and ligation to its cognate receptor on endothelial cells. This desequestration of bound VEGF is, in turn, triggered by the direct induction by Myc of the inflammatory cytokine IL-1 $\beta$, most probably through activation of proteases of the MMP class.
A number of other studies have demonstrated the powerful innate angiogenic activity of Myc both in normal development and tumorigenesis via a number of possible downstream effectors, including down-regulation of thrombospondin-1 (TSP-1), an inhibitor of angiogenesis, and up-regulation of tissue hypoxia factor (HIF$1 \alpha$ ) and VEGF A (Janz et al. 2000; Baudino et al. 2002; Knies-Bamforth et al. 2004). It may be that all, or some, of these intermediaries are involved in Myc-induced tumor angiogenesis in differing tissue types. For example, TSP-1 is down-regulated by activation of Myc in fibroblasts, apparently through an increase in TSP-1 mRNA degradation (Janz et al. 2000). Furthermore, Myc-dependent down-regulation of TSP-1 has recently been implicated in Ras-dependent angiogenesis (Watnick et al. 2003). However, expression array and immunohistochemical analyses reveal no measurable suppression of TSP-1 mRNA or protein in pancreatic islets over the critical time scale in which Myc triggers islet angiogenesis (data not shown), indicating that TSP-1 down-regulation is not the trigger of Myc-mediated angiogenesis in pIns-c-MycER ${ }^{T A M} ; R I P 7-B c l-x_{L}$ model. On the other hand, our data do, clearly, implicate VEGF A as the likely proximal mediator of Myc-induced angiogenesis in $p I n s-c-M y c E R^{T A M} ; R I P 7-B c l-x_{L}$ islets. The kinetics of appearance of active VEGF $A$ in islets coincides perfectly with onset of islet endothelial cell proliferation. Moreover, Myc-induced islet vasculature is both leaky and tortuous, hallmarks of VEGF A action as both endothelial mitogen and vascular remodeling factor.

One potent trigger of angiogenesis is tissue hypoxia. Moreover, hypoxia is likely a direct outcome of the unrestrained and uncoordinated cell expansion that Myc can induce. However, for several reasons hypoxia seems not to be the mechanism driving Myc-induced angiogenesis in pIns-c-MycER ${ }^{T A M} ; R I P 7-B c 1-x_{L}$ islets. First, the onset of endothelial cell cycle entry clearly precedes any overt expansion of the $\beta$-cell compartment that would be needed to generate hypoxic islets. Second, direct analysis of tissue hypoxia using systemic administration of the hypoxia probe pimonidazole hydrochloride in vivo failed to identify any hypoxic regions of islet tissue at the time of endothelial cell proliferation. Third, our data clearly indicate that activation of VEGF A arises not from induction of VEGF A gene or protein expression, as would be expected from hypoxic activation of HIF1 $\alpha$ transcriptional activity, but through the release of existing, sequestered VEGF.

The desequestration from ECM and redistribution of VEGF that Myc activation in $\beta$ cells induces in islets is highly reminiscent of the redistribution of VEGF A that accompanies, and is responsible for, the sporadic angiogenic switch in premalignant islets in the well-characterized RIP-Tag model. At least six distinct isoforms of VEGF are known to be produced via alternate splicing, of which four are expressed appreciably in adult tissues. Of these latter, isoforms $\mathrm{VEGF}_{145}$ and $\mathrm{VEGF}_{189}$ bind tightly to ECM, VEGF ${ }_{165}$ less so, and VEGF 121 not at all (Robinson and Stringer 2001). In RIP-Tag tu- 
mors, release of VEGF is thought to be triggered by the action of metalloproteinases (Bergers et al. 2000). Indeed, MMPs target not only ECM but also the large isoforms of VEGF A itself, clipping off the heparin-binding domain and so releasing diffusible VEGF A (Lee et al. 2005). Nonetheless, while ECM sequestration and subsequent release of VEGF are important in the control of VEGF activity (Park et al. 1993), VEGF activity is also regulated by a wide range of mechanisms, including transcription, mRNA stabilization, translation, protein secretion, and protein-protein interactions (Forsythe et al. 1996; Levy et al. 1996; Valter et al. 1999; Mezquita et al. 2005).

Compared with sporadic models of angiogenic switching such as RIP-Tag (Folkman et al. 1989), it is much easier to investigate the cause and effect sequence of events that triggers the angiogenic switch in the switchable and synchronous pIns-MycER ${ }^{T A M} ; R I P 7-B c l-x_{L}$ mouse model. Myc is thought to exert its biological effects through its action as a transcription factor. We therefore took advantage of the pIns-MycER ${ }^{T A M} ; R I P$ $B c l-x_{L}$ model to identify likely downstream Myc target genes that might mediate angiogenesis. However, none of the obvious candidate genes previously implicated in tumor angiogenesis, including VEGF $B, T N F-\alpha, F G F A$, $P D G F A$, and TSP-1, was notably regulated in the relevant time window. In contrast, the gene encoding IL-1 $\beta$ was significantly and rapidly induced in $\beta$ cells following Myc activation. Given the rapidity of $I L-1 \beta$ mRNA induction by Myc, together with the presence of a noncanonical, potential Myc:Max-binding CACTTG E-box (Blackwell et al. 1993) at position -240 to -234 relative to the $I L-1 \beta$ gene transcriptional start site, it seems plausible that $I L-1 \beta$ is, indeed, a target gene of Myc.

IL- $1 \beta$ is a potent immunoregulatory and proinflammatory cytokine secreted by a variety of activated immune and somatic cells, including Leydig cells of testis, dermal fibroblasts, and vascular endothelial cells as well as pancreatic $\beta$ cells (Warner et al. 1987; Cudicini et al. 1997; Maedler et al. 2002; Naderi-Hachtroudi et al. 2002). Although more typically associated with classical inflammation, IL- $1 \beta$ has also been implicated in angiogenic activity of established mouse tumor cell lines (Voronov et al. 2003) and, very recently, in angiogenesis and invasion in human solid tumors (Elaraj et al. 2006). While IL-1 $\beta$ can directly affect the survival and proliferation of endothelial cells, it can also promote induction of other proangiogenic factors such as $\mathrm{TNF} \alpha$, angiopoietin-1, IL-6, and VEGF A (Voronov et al. 2003; Fan et al. 2004; Alagappan et al. 2005; Stocks et al. 2005). It is especially interesting that IL-1 $\beta$ is a potent inducer and activator of matrix metalloproteinases (Wong et al. 2001; Tasaki et al. 2003; Choi et al. 2004), given the ascribed role for MMP9 in triggering VEGF release during the angiogenic switch in RIP-Tag mice (Bergers et al. 2000) and the dramatic and rapid release of ECM-bound VEGF we see in islets following Myc activation. Indeed, our own studies indicate that inhibiting MMP activity in isolated pIns$M y c E R^{T A M} ; R I P 7-B c 1-x_{L}$ islets in vitro with the MMP inhibitor GM6001 significantly reduces release of VEGF following Myc activation (K. Shchors and G. Evan, unpubl.).
To test our hypothesis that IL-1 $\beta$ is, indeed, the initiating trigger by which Myc engages angiogenesis in islets, we directly inhibited IL- $1 \beta$ activity in vivo by systemic delivery of neutralizing IL- $1 \beta$-specific antibodies. This approach has been successfully employed in the treatment of myocardial infraction (Hwang et al. 2001). Interference with IL-1 $\beta$ activity in patients was also demonstrated to limit IL-1 $\beta$-dependent pathologies like rheumatoid arthritis (Bresnihan et al. 1998) and, with some limitations, sepsis syndrome (Fisher et al. 1994). Using systemic IL-1 $\beta$-blocking antibodies we were able to show unequivocally that inhibition of IL-1 $\beta$ significantly inhibits and delays the capacity of Myc to activate the islet angiogenic switch, confirming a key role for IL- $1 \beta$. This requirement was further confirmed by showing that addition of recombinant IL- $1 \beta$ to isolated islets is sufficient to trigger significant release of VEGF. Thus, IL- $1 \beta$ is both necessary and sufficient as a mediator of the Myc angiogenic switch in $\beta$ cells. Of note, the inhibition of angiogenesis afforded by blocking IL-1 $\beta$ is manifest principally as a delay, rather than as a permanent abrogation. This may reflect incomplete systemic inhibition of IL-1 $\beta$ by the blocking antibodies, a not unusual limitation in such experiments. However, as suggested by many other studies of angiogenic inhibitors, it seems equally likely that Myc-induced angiogenesis, like angiogenesis in general, is mediated by multiple, functionally degenerate pathways. In this context, it is dramatic to achieve such an effect by disabling only a single factor.

The identification of IL-1 $\beta$ as a key mediator of Mycinduced tumor angiogenesis further aligns and overlaps the biological programs that instruct tumorigenesis and inflammation. Both Myc and Ras have been shown to be highly efficacious drivers of neoplasia once their intrinsic tumor suppressor pathways have been circumvented, both efficiently and rapidly inducing tumors with all the "hallmarks" of advanced cancers, including angiogenesis, dysplasia, suppressed apoptosis, invasion, and metastasis (Fisher et al. 1994; Pelengaris et al. 1999, 2002; Tang et al. 2005). As illustrated by the role recently shown to be played by IL- 8 in Ras-induced tumorigenesis (Sparmann and Bar-Sagi 2004), it is clear that highly pleiotropic oncoproteins like Myc and Ras drive cancer so effectively because they commandeer a diverse range of fundamental processes that govern and integrate the dynamics of cells and tissues during development, remodeling, and repair. In this regard, it is encouraging that, within such diverse and diffuse programs, individual and critical effectors like IL- $1 \beta$ can nonetheless be found that may serve as targets for effective therapeutic intervention.

\section{Materials and methods}

Mice, tissue sample generation, manipulation, and preparation

All mice were housed, fed, and treated in accordance with protocols approved by the committee for animal research at the University of California, San Francisco. Transgenic mice ex- 
pressing switchable MycER ${ }^{\mathrm{TAM}}$ and constitutive $\mathrm{Bcl}-\mathrm{x}_{\mathrm{L}}$ in their pancreatic $\beta$ cells ( $p I n s-M y c E R^{T A M}$;RIP7-Bcl- $x_{L}$ mice) have been previously described and characterized (Pelengaris et al. 2002). MycER ${ }^{\text {TAM }}$ was activated in $\beta$ cells in situ by daily i.p. injection of Tamoxifen (TAM) (1 $\mathrm{mg}$ per mouse per day) dissolved in peanut oil (Sigma). TAM is metabolized in vivo to 4-OHT, and early studies in our laboratory confirm their equivalent effects when administered to pIns-MycER ${ }^{T A M} ;$ RIP7-Bcl- $x_{L}$ mice. Pancreata of treated mice were isolated, washed in ice-cold PBS, submerged in $30 \%$ sucrose for $24 \mathrm{~h}$, and embedded in OCT media for sectioning and analysis.

To map and characterize islet and tumor vasculature, mice were anesthetized with $2.5 \%$ Avertin and $100 \mu \mathrm{L}$ of $1: 1$ mixture of FITC-conjugated Lycopersicon esculentum lectin $(1 \mathrm{mg} / \mathrm{mL})$ (FL-1171, Vector Laboratories) and Rhodamine-conjugated Ricinus communis agglutinin I (2.5 mg/mL) (RL-1082, Vector Laboratories) that was diluted in PBS and administered via retroorbital vein. Five minutes later, animals were perfused with $4 \%$ PFA and tissues were processed as described above. Tissue hypoxia was assayed with an Hypoxyprobe-Plus Kit (HP2-100; Chemicon), according to the manufacturer's protocol. In brief, animals were injected i.p. with $60 \mathrm{mg} / \mathrm{kg}$ Hypoxyprobe- 1 (pimonidazole hydrochloride) and $45 \mathrm{~min}$ later were sacrificed and perfused with $4 \%$ PFA. Protein adducts of reductively activated pimonidazole were then identified in tissue sections by staining with Hypoxyprobe-1 monoclonal antibody. To block systemic IL-1 $\beta$ in vivo, mice were injected with $100 \mu \mathrm{g} / 25 \mathrm{~g}$ of either IL-1 $\beta$-neutralizing antibody (AB-401-NA, R\&D Systems) or control goat IgG (0109-10, Southern Biotech). Treatment was initiated $24 \mathrm{~h}$ prior to the first injection of TAM and then readministered daily for the duration of each experiment. To assay circulating IL-1 $\beta$ levels, blood samples were collected before and after antibody administration, and serum IL-1 $\beta$ levels were determined by ELISA as described below. Pancreata of antibodytreated mice were isolated and processed as described above.

\section{Histology and immunofluorescence}

Ten-micrometer OCT-embedded tissue sections were air-dried and fixed for $30 \mathrm{~min}$ in $1 \%$ paraformaldehyde solution. The primary antibodies used were as follows: rabbit polyclonal antimurine VEGF A (RDI-mVEGFabrP1; RDI), rat monoclonal antiMeca-32 (550563; BD Pharmingen), mouse monoclonal GVM39 anti-murine VEGF:VEGFR conjugates (CD300; EastCoast Bio), and rabbit monoclonal anti-Ki67 (RM 9106; Labvision,). All were applied in blocking buffer (2.5\% BSA, 5\% goat serum) for 2-16 h. Secondary antibodies (Dako and Molecular Probes) were applied in blocking buffer for $1 \mathrm{~h}$. To identify regions of tissue hypoxia, fixed sections were incubated with FITC-Hypoxyprobe-1 MAb1 in blocking buffer for $1 \mathrm{~h}$ at room temperature. To identify regions of staining by fluorescent lectins, $30-\mu \mathrm{m}$ tissue sections were air dried and fixed for $10 \mathrm{~min}$ in ice-cold acetone. Slides were then rinsed in PBS and mounted in DAKO fluorescent mounting medium containing $1 \mu \mathrm{g} / \mathrm{mL}$ Hoechst. Fluorescent images were obtained using an LSM510 confocal microscope (Zeiss) or an axiovert 100 inverted microscope (Zeiss) equipped with a Hamamatsu Orca digital camera, running Openlab 3.5.1 software.

Endothelial cell proliferation was quantified in tissue sections by counting randomized fields of (Meca-32-positive) endothelial cells and calculating the percentage of Ki67-positive cells. At least three animals were assayed at each time point and all analyses done in duplicate; 10 randomized fields per staining were considered. Statistical significance was assessed using the Student's $t$-test. The minimum level of significance was set at $P \leq 0.001$.

\section{Isolation of pancreatic islets and quantitative real-time PCR}

Pancreata from $p I n s-M y c E R^{T A M} ; R I P 7-B c l-x_{L}$ and Myc-negative $R I P 7-B c 1-x_{L}$ mice were inflated with $4 \mathrm{~mL}$ of $0.7 \mathrm{mg} / \mathrm{mL}$ Collagenase P solution (Sigma) in $1 \times$ Hanks Balanced Salt Solution (CCF, UCSF). Isolated pancreata were then cut into small (1$\mathrm{mm}^{3}$ ) pieces, transferred to siliconized glass vials, and incubated with gentle shaking for $15-20 \mathrm{~min}$ at $37^{\circ} \mathrm{C}$ in $2 \mathrm{~mL}$ of the collagenase solution. Digested pancreata were washed twice in ice-cold $1 \times$ Hanks' Balance Salt Solution and intact islets were hand-picked from surrounding exocrine tissue under a stereomicroscope. For short-term culture, isolated islets were maintained in serum-free RPMI 1640 (supplemented with $2 \mathrm{mM} \mathrm{L}$ glutamine and antibiotics) either in the presence of $100 \mathrm{nM}$ 4-OHT or $0.1 \%$ ethanol control for $4 \mathrm{~h}$. Total RNA was isolated from islets using an RNeasy Mini Kit (Qiagen). Each analysis was conducted in triplicate. Crude RNA samples were treated with DNase I, and RNA quantified (Ribogreen, Molecular Probes). Total islet RNA was reverse transcribed into first strand cDNA using the iScript Reverse Transcriptase kit as per the manufacturer's instructions (Bio-Rad). Levels of expression of target genes were determined using standardized TaqMan Assays-on-Demand (Applied Biosystems) analyzed using an ABI Prism 7700 PCR sequence detector (Perkin-Elmer Applied Biosystems). Each RNA sample was amplified and analyzed in triplicate and the level of expression determined the average of the three relative to the level of expression of $\beta$-glucuronidase (Gus). Statistical validity was assessed using the Student's ttest.

\section{In vitro analysis of islet proangiogenic activity and cytokine} production

To assay VEGF A release and angiogenic activity of isolated islets in vitro, freshly purified islets (50 islets/well in a 48 -well plate) were resuspended in $20 \mu \mathrm{L}$ Fibrinogen (Sigma) and an equal volume of thrombin solution $(50 \mathrm{U} / \mathrm{mL}$ in $40 \mathrm{mM} / \mathrm{L}$ $\mathrm{CaCl}_{2}$; Sigma) (Beattie et al. 2002). The fibrinogen was allowed to polymerize (10-15 $\mathrm{min}$ ) and $1 \mathrm{~mL}$ of culture medium was then added over the fibrin sandwich. For ELISA quantitation of VEGF A, fibrin-embedded islets (50 islets/well in a 48 -well plate) were cultured in $1 \mathrm{~mL}$ of serum-free RPMI 1640 (supplemented with $2 \mathrm{mM}$ L-glutamine and antibiotics) in the presence of either $100 \mathrm{nM} 4-\mathrm{OHT}$ or ethanol carrier. To block IL-1 $\beta$ activity in vitro, either IL-1 $\beta$-neutralizing antibodies (AF-401-NA; $\mathrm{R} \& D)$ or control anti-goat IgG (401,514; Calbiochem) were added to the RPMI 1640 medium in a $0.1 \mu \mathrm{g} / \mathrm{mL}$ concentration. To assess the direct potential of IL-1 $\beta$ to induce VEGF A release in vitro, $10 \mathrm{ng} / \mathrm{mL}$ of recombinant IL-1 $\beta$ (401-ML; R\&D) was added to the RPMI 1640 islet culture medium for $72 \mathrm{~h}$, and VEGF was released in the conditioned medium then assayed by ELISA. In vitro angiogenesis assays were performed by culturing islets (50 islets/well in a 48-well plate) for $72 \mathrm{~h}$ in $1 \mathrm{~mL}$ of EBM (CC-3156; BioWhittaker) supplemented with 1\% BSA. HUVEC cells were then exposed to the conditioned medium for a further $72 \mathrm{~h}$ in a fibrin gel angiogenesis kit (ECM630, Chemicon) according to the manufacturer's protocol. The HUVEC cells were obtained from Cambrex (CC-2517). To quantitate angiogenesis in vitro, plates of HUVEC were washed twice in PBS and the cells were fixed in $2 \%$ PFA overnight at $4^{\circ} \mathrm{C}$. The plates were then washed in PBS and cell nuclei were stained by $1 \mu \mathrm{g} / \mathrm{mL}$ Hoechst in $40 \%$ glycerol. Images were obtained with an axiovert 100 inverted microscope (Zeiss) equipped with a Hamamatsu Orca digital camera, running Openlab 3.5.1 software. The percent of HUVEC nuclei incorporated into tubes over total HUVEC nuclei was then determined. Each experiment was re- 
peated twice, and three independent wells were counted for every point. Statistical analysis used the Student's $t$-test. Quantitation of mouse cytokines was performed by Super-ELISA (Biotraces, Inc.) according to the proprietary protocol (see http:// www.biotraces.com for more information) using commercially available antibodies (R\&D Systems). Mouse VEGF (mVEGF) was detected with mVEGF-specific antibodies AF-493NA and BAF493, and IL-1 $\beta$ was detected with antibodies MAB401 and BAF401.

Laser-capture microdissection, Affymetrix GeneChip Arrays, data analysis, and promoter studies

Laser-capture microdissection, RNA amplification, Affymetrix Array, and data analysis were all performed as described previously (Lawlor et al. 2006). Gene2Promoter and MatInspector programs of the Genomatix software package (http://www. genomatix.de/products/Gene2Promoter/index.html) (Quandt et al. 1995) were used to identify gene promoter sequences and the presence of E-boxes therein. E-box searches for potential Myc: Max recognition elements (Genomatix) were limited to genomic sequences 1000 base pair (bp) upstream and 500 bp downstream of the transcription start site.

\section{Acknowledgments}

We are grateful to Dr. Andrew Finch (UCSF) and Dr. Laura Soucek (UCSF) for critical reading of the manuscript, as well as to our colleagues, in particular members of the Evan, Coussens, Hanahan, and Werb laboratories at UCSF, for their invaluable criticism and advice. This work was supported by NIH grant R01 CA98018 (NCI) to G.I.E. K.S. is a recipient of F32CA106039.

\section{REFERENCES}

Abraham, D., Taghavi, S., Riml, P., Paulus, P., Hofmann, M., Baumann, C., Kocher, A., Klepetko, W., and Aharinejad, S. 2002. VEGF-A and -C but not -B mediate increased vascular permeability in preserved lung grafts. Transplantation 73: 1703-1706.

Alagappan, V.K., McKay, S., Widyastuti, A., Garrelds, I.M., Bogers, A.J., Hoogsteden, H.C., Hirst, S.J., and Sharma, H.S. 2005. Proinflammatory cytokines upregulate mRNA expression and secretion of vascular endothelial growth factor in cultured human airway smooth muscle cells. Cell Biochem. Biophys. 43: 119-129.

Baudino, T.A., McKay, C., Pendeville-Samain, H., Nilsson, J.A., Maclean, K.H., White, E.L., Davis, A.C., Ihle, J.N., and Cleveland, J.L. 2002. c-Myc is essential for vasculogenesis and angiogenesis during development and tumor progression. Genes \& Dev. 16: 2530-2543.

Beattie, G.M., Montgomery, A.M., Lopez, A.D., Hao, E., Perez, B., Just, M.L., Lakey, J.R., Hart, M.E., and Hayek, A. 2002. A novel approach to increase human islet cell mass while preserving $\beta$-cell function. Diabetes 51: 3435-3439.

Bergers, G., Brekken, R., McMahon, G., Vu, T.H., Itoh, T., Tamaki, K., Tanzawa, K., Thorpe, P., Itohara, S., Werb, Z., et al. 2000. Matrix metalloproteinase- 9 triggers the angiogenic switch during carcinogenesis. Nat. Cell Biol. 2: 737-744.

Blackwell, T.K., Huang, J., Ma, A., Kretzner, L., Alt, F.W., Eisenman, R.N., and Weintraub, H. 1993. Binding of myc proteins to canonical and noncanonical DNA sequences. Mol. Cell. Biol. 13: 5216-5224.

Brandvold, K.A., Neiman, P., and Ruddell, A. 2000. Angiogen- esis is an early event in the generation of myc-induced lymphomas. Oncogene 19: 2780-2785.

Bresnihan, B., Alvaro-Gracia, J.M., Cobby, M., Doherty, M., Domljan, Z., Emery, P., Nuki, G., Pavelka, K., Rau, R., Rozman, B., et al. 1998. Treatment of rheumatoid arthritis with recombinant human interleukin-1 receptor antagonist. Arthritis Rheum. 41: 2196-2204.

Choi, Y.A., Lee, D.J., Lim, H.K., Jeong, J.H., Sonn, J.K., Kang, S.S., and Baek, S.H. 2004. Interleukin-1 $\beta$ stimulates matrix metalloproteinase-2 expression via a prostaglandin E2-dependent mechanism in human chondrocytes. Exp. Mol. Med. 36: 226-232.

Cudicini, C., Lejeune, H., Gomez, E., Bosmans, E., Ballet, F., Saez, J., and Jegou, B. 1997. Human Leydig cells and Sertoli cells are producers of interleukins-1 and -6. J. Clin. Endocrinol. Metab. 82: 1426-1433.

Dvorak, H.F. 2002. Vascular permeability factor/vascular endothelial growth factor: A critical cytokine in tumor angiogenesis and a potential target for diagnosis and therapy. J. Clin. Oncol. 20: 4368-4380.

Elaraj, D.M., Weinreich, D.M., Varghese, S., Puhlmann, M., Hewitt, S.M., Carroll, N.M., Feldman, E.D., Turner, E.M., and Alexander, H.R. 2006. The role of interleukin 1 in growth and metastasis of human cancer xenografts. Clin. Cancer Res. 12: 1088-1096.

Fan, F., Stoeltzing, O., Liu, W., McCarty, M.F., Jung, Y.D., Reinmuth, N., and Ellis, L.M. 2004. Interleukin- $1 \beta$ regulates angiopoietin-1 expression in human endothelial cells. Cancer Res. 64: 3186-3190.

Finch, A.J., Prescott, J., Shchors, K., Hunt, A., Soucel, L., Dansen, T.D., Brown Swigart, L., and Evan, G.I. 2006. Bcl- $\mathrm{x}_{\mathrm{L}}$ gain of function and ARF loss of function cooperate oncogenically with Myc in vivo by distinct mechanisms. Cancer Cell (in press).

Fisher Jr., C.J., Dhainaut, J.F., Opal, S.M., Pribble, J.P., Balk, R.A., Slotman, G.J., Iberti, T.J., Rackow, E.C., Shapiro, M.J., Greenman, R.L., et al. 1994. Recombinant human interleukin 1 receptor antagonist in the treatment of patients with sepsis syndrome. Results from a randomized, double-blind, placebo-controlled trial. Phase III rhIL-1ra Sepsis Syndrome Study Group. JAMA 271: 1836-1843.

Folkman, J., Watson, K., Ingber, D., and Hanahan, D. 1989. Induction of angiogenesis during the transition from hyperplasia to neoplasia. Nature 339: 58-61.

Forsythe, J.A., Jiang, B.H., Iyer, N.V., Agani, F., Leung, S.W., Koos, R.D., and Semenza, G.L. 1996. Activation of vascular endothelial growth factor gene transcription by hypoxia-inducible factor 1. Mol. Cell. Biol. 16: 4604-4613.

Fotsis, T., Breit, S., Lutz, W., Rossler, J., Hatzi, E., Schwab, M., and Schweigerer, L. 1999. Down-regulation of endothelial cell growth inhibitors by enhanced MYCN oncogene expression in human neuroblastoma cells. Eur. J. Biochem. 263: 757-764.

Freeburg, P.B. and Abrahamson, D.R. 2004. Divergent expression patterns for hypoxia-inducible factor- $1 \beta$ and aryl hydrocarbon receptor nuclear transporter-2 in developing kidney. J. Am. Soc. Nephrol. 15: 2569-2578.

Harris, A.L. 2002. Hypoxia-A key regulatory factor in tumour growth. Nat. Rev. Cancer 2: 38-47.

Hwang, M.W., Matsumori, A., Furukawa, Y., Ono, K., Okada, M., Iwasaki, A., Hara, M., Miyamoto, T., Touma, M., and Sasayama, S. 2001. Neutralization of interleukin-1 $\beta$ in the acute phase of myocardial infarction promotes the progression of left ventricular remodeling. J. Am. Coll. Cardiol. 38: 1546-1553.

Janz, A., Sevignani, C., Kenyon, K., Ngo, C.V., and Thomas- 
Tikhonenko, A. 2000. Activation of the myc oncoprotein leads to increased turnover of thrombospondin-1 mRNA. Nucleic Acids Res. 28: 2268-2275.

Knies-Bamforth, U.E., Fox, S.B., Poulsom, R., Evan, G.I., and Harris, A.L. 2004. c-Myc interacts with hypoxia to induce angiogenesis in vivo by a vascular endothelial growth factordependent mechanism. Cancer Res. 64: 6563-6570.

Lawlor, E.R., Soucek, L., Brown-Swigart, L., Shchors, K., Bialucha, C.U., and Evan, G.I. 2006. Reversible kinetic analysis of Myc targets in vivo provides novel insights into Mycmediated tumorigenesis. Cancer Res. 66: 4591-4601.

Lee, S., Jilani, S.M., Nikolova, G.V., Carpizo, D., and IruelaArispe, M.L. 2005. Processing of VEGF-A by matrix metalloproteinases regulates bioavailability and vascular patterning in tumors. J. Cell Biol. 169: 681-691.

Levy, A.P., Levy, N.S., and Goldberg, M.A. 1996. Post-transcriptional regulation of vascular endothelial growth factor by hypoxia. J. Biol. Chem. 271: 2746-2753.

Maedler, K., Sergeev, P., Ris, F., Oberholzer, J., Joller-Jemelka, H.I., Spinas, G.A., Kaiser, N., Halban, P.A., and Donath, M.Y. 2002. Glucose-induced $\beta$ cell production of IL-1 $\beta$ contributes to glucotoxicity in human pancreatic islets. J. Clin. Invest. 110: 851-860.

Mezquita, P., Parghi, S.S., Brandvold, K.A., and Ruddell, A. 2005. Myc regulates VEGF production in B cells by stimulating initiation of VEGF mRNA translation. Oncogene 24: 889-901.

Naderi-Hachtroudi, L., Peters, T., Brenneisen, P., Meewes, C., Hommel, C., Razi-Wolf, Z., Schneider, L.A., Schuller, J., Wlaschek, M., and Scharffetter-Kochanek, K. 2002. Induction of manganese superoxide dismutase in human dermal fibroblasts: A UV-B-mediated paracrine mechanism with the release of epidermal interleukin $1 \alpha$, interleukin $1 \beta$, and tumor necrosis factor $\alpha$. Arch. Dermatol. 138: 1473-1479.

Ngo, C.V., Gee, M., Akhtar, N., Yu, D., Volpert, O., Auerbach, R., and Thomas-Tikhonenko, A. 2000. An in vivo function for the transforming Myc protein: Elicitation of the angiogenic phenotype. Cell Growth Differ. 11: 201-210.

Osenkowski, P., Toth, M., and Fridman, R. 2004. Processing, shedding, and endocytosis of membrane type 1-matrix metalloproteinase (MT1-MMP). J. Cell. Physiol. 200: 2-10.

Park, J.E., Keller, G.A., and Ferrara, N. 1993. The vascular endothelial growth factor (VEGF) isoforms: Differential deposition into the subepithelial extracellular matrix and bioactivity of extracellular matrix-bound VEGF. Mol. Biol. Cell 4: 1317-1326.

Pelengaris, S., Littlewood, T., Khan, M., Elia, G., and Evan, G. 1999. Reversible activation of c-Myc in skin: Induction of a complex neoplastic phenotype by a single oncogenic lesion. Mol. Cell 3: 565-577.

Pelengaris, S., Khan, M., and Evan, G.I. 2002. Suppression of Myc-induced apoptosis in $\beta$ cells exposes multiple oncogenic properties of Myc and triggers carcinogenic progression. Cell 109: 321-334.

Quandt, K., Frech, K., Karas, H., Wingender, E., and Werner, T. 1995. MatInd and MatInspector: New fast and versatile tools for detection of consensus matches in nucleotide sequence data. Nucleic Acids Res. 23: 4878-4884.

Robinson, C.J. and Stringer, S.E. 2001. The splice variants of vascular endothelial growth factor (VEGF) and their receptors. J. Cell Sci. 114: 853-865.

Semenza, G.L. 2001. Hypoxia-inducible factor 1: Oxygen homeostasis and disease pathophysiology. Trends Mol. Med. 7: 345-350.

Sparmann, A. and Bar-Sagi, D. 2004. Ras-induced interleukin-8 expression plays a critical role in tumor growth and angio- genesis. Cancer Cell 6: 447-458.

Stocks, J., Bradbury, D., Corbett, L., Pang, L., and Knox, A.J. 2005. Cytokines upregulate vascular endothelial growth factor secretion by human airway smooth muscle cells: Role of endogenous prostanoids. FEBS Lett. 579: 2551-2556.

Tang, Y., Kim, M., Carrasco, D., Kung, A.L., Chin, L., and Weissleder, R. 2005. In vivo assessment of RAS-dependent maintenance of tumor angiogenesis by real-time magnetic resonance imaging. Cancer Res. 65: 8324-8330.

Tasaki, K., Shintani, Y., Saotome, T., Andoh, A., Fujiyama, Y., Hozawa, S., and Bamba, T. 2003. Pro-inflammatory cytokine-induced matrix metalloproteinase-1 (MMP-1) secretion in human pancreatic periacinar myofibroblasts. Pancreatology 3: 414-421.

Valter, M.M., Wiestler, O.D., and Pietsche, T. 1999. Differential control of VEGF synthesis and secretion in human glioma cells by IL-1 and EGF. Int. J. Dev. Neurosci. 17: 565-577.

Voronov, E., Shouval, D.S., Krelin, Y., Cagnano, E., Benharroch, D., Iwakura, Y., Dinarello, C.A., and Apte, R.N. 2003. IL-1 is required for tumor invasiveness and angiogenesis. Proc. Natl. Acad. Sci. 100: 2645-2650.

Warner, S.J., Auger, K.R., and Libby, P. 1987. Interleukin 1 induces interleukin 1 . II. Recombinant human interleukin 1 induces interleukin 1 production by adult human vascular endothelial cells. I. Immunol. 139: 1911-1917.

Watnick, R.S., Cheng, Y.N., Rangarajan, A., Ince, T.A., and Weinberg, R.A. 2003. Ras modulates Myc activity to repress thrombospondin-1 expression and increase tumor angiogenesis. Cancer Cell 3: 219-231.

Wong, W.R., Kossodo, S., and Kochevar, I.E. 2001. Influence of cytokines on matrix metalloproteinases produced by fibroblasts cultured in monolayer and collagen gels. J. Formos. Med. Assoc. 100: 377-382. 


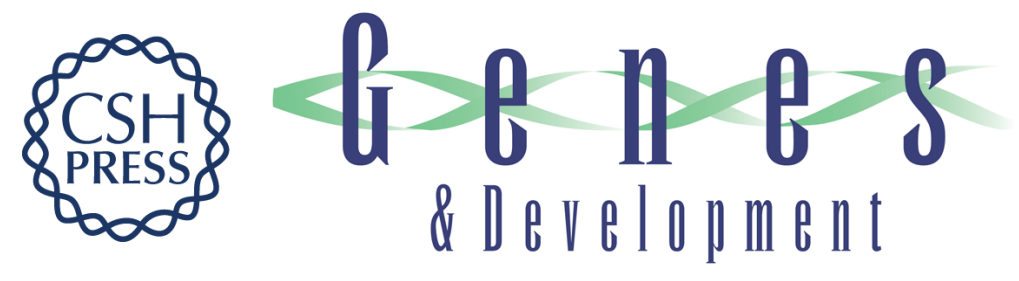

\section{The Myc-dependent angiogenic switch in tumors is mediated by interleukin $1 \beta$}

Ksenya Shchors, Elena Shchors, Fanya Rostker, et al.

Genes Dev. 2006, 20:

Access the most recent version at doi:10.1101/gad.1455706

\section{Supplemental http://genesdev.cshlp.org/content/suppl/2006/09/18/20.18.2527.DC1 Material}

Related Content

References

This article cites 45 articles, 18 of which can be accessed free at: http://genesdev.cshlp.org/content/20/18/2527.full.html\#ref-list-1

Articles cited in:

http://genesdev.cshlp.org/content/20/18/2527.full.html\#related-urls

\section{License}

Email Alerting

Service

From Myc Activation to Angiogenesis

Nancy R. Gough

Sci. STKE September , 2006 2006: tw330

Receive free email alerts when new articles cite this article - sign up in the box at the top right corner of the article or click here.

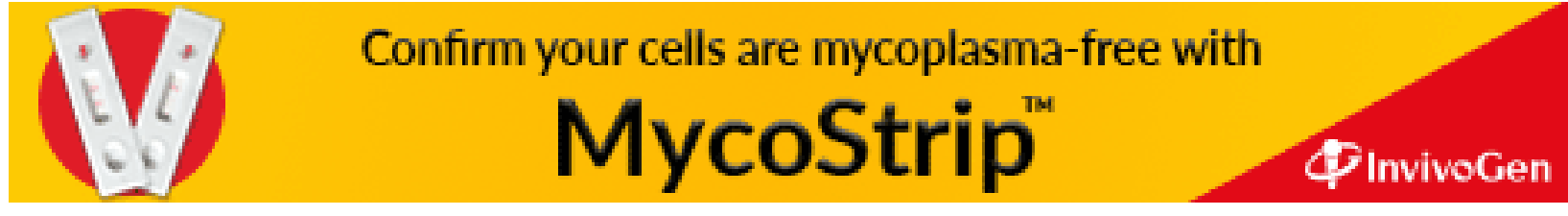

